\title{
Land Cover Dynamics in the Kirisia Forest Ecosystem, Samburu County, Kenya
}

\author{
Fiesta Warinwa ${ }^{1}$, Francis Mwaura ${ }^{2 \#, ~ J o h n ~ W a r u i ~ K i r i n g e s ~}{ }^{3}$, Antony Oduya Ndubi ${ }^{4}$ \\ ${ }^{1}$ African Wildlife Foundation (AWF), Nairobi, Kenya \\ ${ }^{2}$ Department of Geography \& Environmental Studies, University of Nairobi, Nairobi, Kenya \\ ${ }^{3}$ Habitat Planners \& Environmental Consultants Ltd, Nairobi, Kenya \\ ${ }^{4}$ Regional Centre for Mapping of Resources for Development (RCMRD), SERVIR Eastern and Southern Africa \\ Project, Nairobi, Kenya \\ Email: "mwauraf@uonbi.ac.ke
}

Received 19 May 2016; accepted 2 August 2016; published 5 August 2016

Copyright (C) 2016 by authors and Scientific Research Publishing Inc.

This work is licensed under the Creative Commons Attribution International License (CC BY).

http://creativecommons.org/licenses/by/4.0/

(c) (i) Open Access

\begin{abstract}
The study characterized the status and trend of land cover transformation in Kirisia forest ecosystem between 1973 and 2015 using remote sensing and GIS. The dominant land cover types consisted of indigenous forest followed by shrub land and bush land. The findings showed a major increase in the built environment by $55.4 \%$ and an overall reduction in forest cover by $21.3 \%$. Up to $83.9 \mathrm{~km}^{2}$ of the original indigenous forest was lost between 1973 and 1986 due to severe fires. Thereafter, $23.7 \mathrm{~km}^{2}$ of the remaining indigenous forest was lost between 1986 and 2000 mainly through charcoal burning, illegal timber logging and livestock forage harvesting. A slight recovery occurred between 2000 and 2015 with a 5\% increase in indigenous forest cover mostly through natural succession by shrub land and bush land in the burnt forest areas especially following the $1998 \mathrm{El}$ Nino period. The land cover change in the forest ecosystem was not exceptional in Kenya but mirrors similar changes that have been documented in other valued dry land watershed ecosystems in the country including the national water towers. The continued loss of forest cover is likely to affect the water recharge capacity in the watershed thereby creating severe water scarcity for the people in Mararal town as well as nearly 142,954 other individuals in the Kirisia region. Appropriate interventions are therefore needed to mitigate the negative land cover change in Kirisia forest and restore its hydrological functions and water recharge capacity.
\end{abstract}

\section{Keywords}

Kirisia Watershed Ecosystem, Forest Cover, Water Supply

\footnotetext{
"This study was funded by the African Wildlife Foundation (AWF).

"Corresponding author.
}

How to cite this paper: Warinwa, F., Mwaura, F., Kiringe, J.W. and Ndubi, A.O. (2016) Land Cover Dynamics in the Kirisia Forest Ecosystem, Samburu County, Kenya. Advances in Remote Sensing, 5, 168-182. 


\section{Introduction}

Forest ecosystems have historically played a key role in supporting the livelihoods of many communities especially in developing countries. In Africa for instance, the importance of forests is epitomized by most hunter-gather societies whose source of food and livelihood needs are largely obtained from animal and plant resources in forests [1] [2]. Rural and urban societies also depend directly or indirectly on forests due to their high reliance on natural resources [3]. Many communities in Africa still rely on forests for wild fruits, honey, construction materials, herbal medicines and household income [2]-[4].

Kenya's forest ecosystems are considered as valued assets because of their resource provisioning and ecosystem services [5]-[7]. They also provide direct and indirect livelihood opportunities for society and contribute significantly towards economic development [6]-[9]. Traditional economic valuation of forests has however tended to concentrate on their consumptive benefits such as the extraction of timber products [6]-[8]. In return, this consideration has encouraged agricultural and logging activities instead of the more sustainable non-consumptive and indirect benefits thereby leading to widespread deforestation and huge losses of valued forest ecosystem services [10] [11]. Watershed ecosystem services (WES) represents one of the most important roles of forest ecosystems because such areas normally act as hydrologic powerhouses due to their ability to intercept rainfall and supply water to urban and rural communities. Consequently, the Government of Kenya has recognized the forest ecosystems in mountain areas as "Water Towers" whose management has recently been entrusted to the Kenya Water Towers Agency (KWTA) whose principal task is to oversee their management with a view of sustaining social-economic development in the country.

Despite the high value of forests in Kenya, these areas have continued to suffer from wanton destruction through unsustainable exploitation of their consumptive benefits thereby threatening their watershed ecosystem services in a very serious way [6]-[10]. It was estimated that between the 1970s and 2010 alone, deforestation in the country's prime water towers amounted to over $500 \mathrm{~km}^{2}$ [12]. In Mt. Elgon, a 34\% reduction in forest cover was recorded between 1995 and 2006 alone while the Cherangani Hills recorded a reduction in forest cover from 465 to $240 \mathrm{~km}^{2}$ between 1973 and 2009 [13]. In the Mau escarpment which is a regional water tower in the country, because it supplies water upto Sudan and Egypt, the forest cover declined from $4695 \mathrm{~km}^{2}$ to $4041 \mathrm{~km}^{2}$ between 1985 and 2010 which translated to an annual decline of about 8.7\% [13] [14]. However, in the Aberdares Ranges which was another important watershed, the forest cover had been relatively stable and was estimated at $2064 \mathrm{~km}^{2}$ in 1985 with only a minor decline to $2061 \mathrm{~km}^{2}$ in 2010 mostly through accidental fires [13]. The Aberdares forest is protected through a $400 \mathrm{~km}$ all-round electrified fence.

Land cover change in Kenya has also been recorded in a number of dry land water towers. For instance, in Mt. Marsabit, the forest cover was approximately $240 \mathrm{~km}^{2}$ in 1985 and declined thereafter to about $132 \mathrm{~km}^{2}$ in 2010 which was mostly attributed to the rapid expansion of Marsabit town [13]. A study by [15] in the area recorded a 32\% reduction in forest cover between 1973 and 2005 due to increased sedentarization of pastoral communities around the forest leading to a huge increase (700\%) in agricultural encroachment of the forest. Elsewhere, studies in the Taita hills within the Taita Taveta County have showed that although significant land use changes have taken place, the forest cover increased significantly from $270 \mathrm{~km}^{2}$ to $414 \mathrm{~km}^{2}$ between 1985 and 2010 as a result of agro forestry and introduction of forest plantations [13] [16] [17]. The Taita hills covering approximately $1000 \mathrm{~km}^{2}$ constitute the northern section of the Eastern Arc Ecoregion and the only one in Kenya.

The deforestation of critical watershed ecosystems has been established to cause significant changes in the magnitude and seasonality of water discharge in springs, streams and rivers [18]-[20]. Numerous studies have demonstrated that substantial changes in hydrological regimes can arise due to land cover changes especially the decline in forests due to their influence on rainfall interception, evapotranspiration, infiltration and surface runoff [21]. Rampant deforestation in Kenya's water towers has consequently been observed to cause massive reduction in water discharge in some valued springs, streams and rivers thereby creating serious water supply deficits for people, livestock and wildlife especially during the dry season [7] [13]. The consequences of this food security and local livelihoods are enormous, far-reaching, long-lasting and are likely to affect the realization of Vision 2030 as well as the global Sustainable Development Goals (SDGs) especially SDG-6 on water and sanitation which aims at ensuring availability and sustainable management of water and sanitation for all. It is therefore imperative that forest cover change is monitored on a regular basis especially within the country's treasured watersheds.

Kirisia Forest is a key dryland water tower in a region of water scarcity. The forest is the life-line for numer- 
ous households, thousands of livestock and a wide range of wildlife populations because Samburu County is largely semi-arid and water deficient. The forest ecosystem is therefore critical in the provision of valued watershed services. Unfortunately, the environmental integrity of the ecosystem has continued to be threatened by all manner of anthropogenic activities such as charcoal burning and illegal timber logging [22]-[25]. At the same time, Kirisia forest has not been adequately considered in the previous land cover change studies undertaken in Kenya and yet it is a critical lifeline ecosystem especially with regard to water supply for the Mararal town. The implementation of the Lamu Port-South Sudan-Ethiopia Transport (LAPPSET) corridor project is likely to attract more people to Mararal thereby leading to higher water demand. In this regard, an understanding of the land cover status and dynamics in Kirisia Forest is important since it has a direct impact on the hydrological capacity of the watershed and provision of water to the Mararal town and other settlements in Samburu County.

Digital change detection techniques using multi-temporal satellite imagery has emerged as a reliable and cost effective method in the monitoring of spatio-temporal landcover dynamics in watershed ecosystems [26]-[28]. This approach is convenient because it exploits the regular data acquisition capacity of space technology through the use of satellites for the detection, mapping and quantification of land cover change. The aim of this study was to: 1) analyse and characterize the current status of land cover in the Kirisia forest ecosystem using remote sensing and geographic information system (GIS); 2) analyse recent land cover changes in the watershed; 3) compare the land cover change with other areas in Kenya. The two technical limitations experienced in the study included the use of an inconsistent temporal interval in the digital imagery time series with a focus on 1976, 1986, 2000 and 2015. This was due to the lack of cloudy free images in some years. Secondly, field data validation was only based on the most recent satellite image (2015) because it was not possible to go back in time and ground truth for the digital images in the previous years.

\section{Study Area}

Kirisia Forest also known as Leroghi is located in the northern section of Kenya within Samburu Central Sub-County of Samburu Country (Figure 1). The forest is situated within the Leroghi plateau and lies on the northern end of the Laikipia plateau in Northern Kenya [22]-[24]. It is one of the oldest state forest reserves in Kenya having been gazetted in 1933 [22] [29]. The forest, which is located at an altitude of $2000-2200 \mathrm{~m}$, was initially covering approximately $920 \mathrm{~km}^{2}$ but has now reduced to less than $780 \mathrm{~km}^{2}$ [22]-[24] [30]. The Leroghi region within which Kirisia forest is situated is largely semi-arid and dominated by ecological zones IV-VI with a mean annual rainfall of around $551 \mathrm{~mm}$ [22] [23] [29]. Due to its higher elevation and rainfall, the forest serves as an important water catchment area, with surface water from the forest emerging downstream in the form of springs and ephemeral streams and laggas [29]. The northern sections of the forest in areas such as Porror usually receive more rainfall at $575 \mathrm{~mm}$ compared to the central and southern regions around Mararal town and Baawa area which receive an average of 563 and $552 \mathrm{~mm}$, respectively. The north eastern section of the forest can therefore be considered as the hydrological powerhouse for the forest ecosystem [12].

[31] described the floral composition of Kirisia forest and indicated that it is characterized by diverse vegetation associations with four woody species dominating the top canopy, namely, Olea europaea spp africana (34\%), Juniperus procera (25\%), Podocarpus falcatus (26\%) and Croton megalocarpus (15\%). The species dominating the middle canopy are P. falcatus (12\% - 45\%), Olea. europaea spp a fricana (21\% - 28\%), Juniperus procera (20\%), Teclea simplicifolia (13\% - 15\%) and Croton megalocarpus (12\%). According to [31], the disturbed and rocky areas of the forest are characterized by small sized trees and shrubs such as Euclea divinorum, Carissa edulis, Rhus natalensis and Croton dichogamus. The forest supports a wide range of fauna including avian species [32]. According to [22]-[24], the forest is endowed with diverse wildlife species such as the cape buffalo (Syncerus cafer), elephant (Loxondonta africana), common zebra (Equus burchelli), olive baboon (Papio anubis), common warthog (Phacochoerus aethiops), bush-buck (Tragelaphus scriptus), lion (Panthera leo), spotted hyena (Crocuta crocuta), Maasai giraffe (Giraffa camoleopardis tippelskirchi), eland (Taurotagus oryx) and giant forest hog (Hylochoerus meinertzhageni).

The main inhabitants of the Kirisia Forest are the Samburu people who are predominantly semi-nomadic pastoralists who are closely related to the Maasai. Most of the communities living adjacent to the forest are settled in 13 group ranches which were part of the 159 group ranches established in the Rift Valley region of Kenya under the Kenya Livestock Development Project of 1968-1980 [33]. These group ranches were also established in Kajiado, Narok, Laikipia, Baringo and West Pokot. A group ranch is a form of communal land tenure consisting 


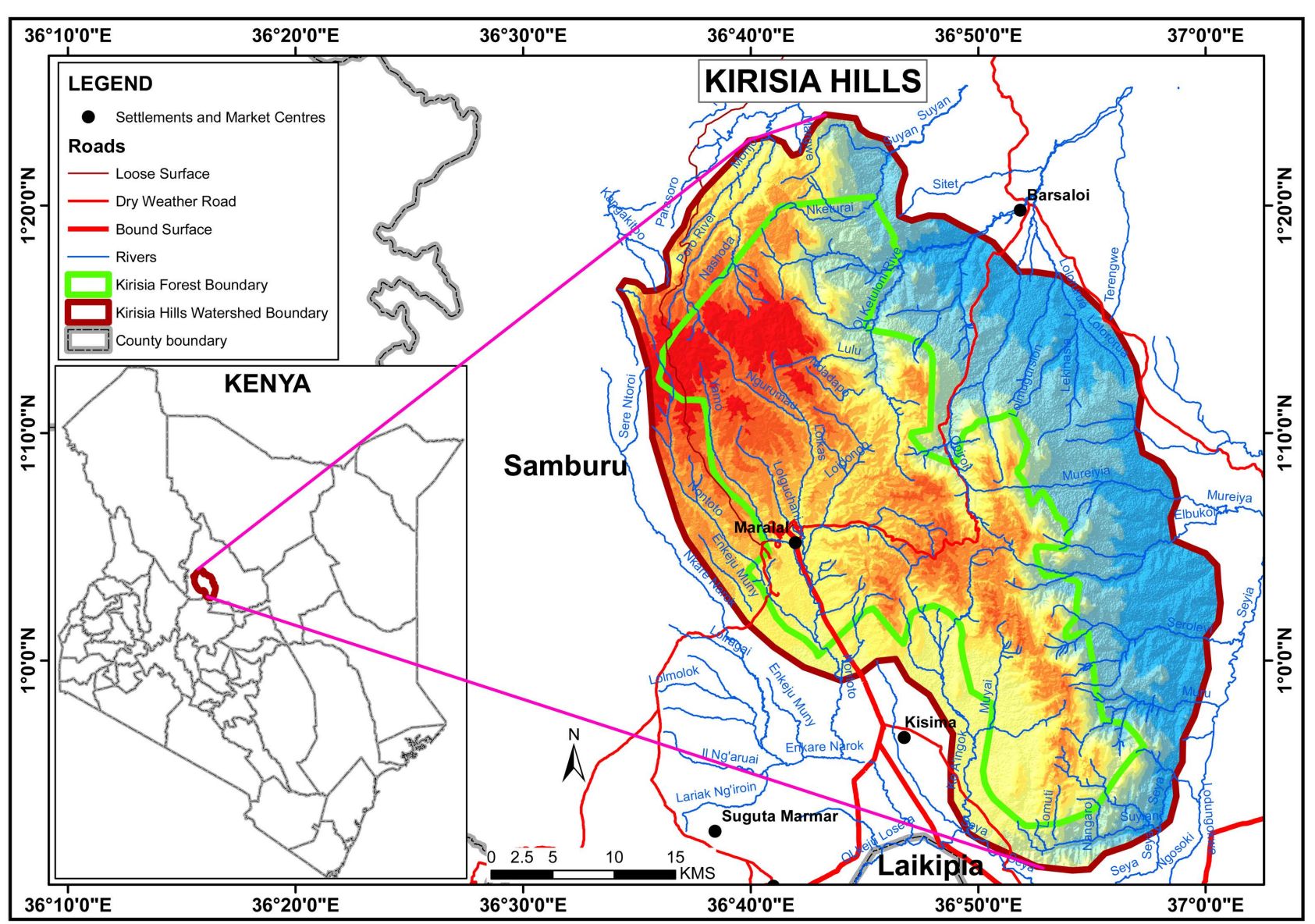

Figure 1. Location of Kirisia forest and its watershed in Samburu county.

of a common land title with shares allocated to the senior members of the beneficiary families. In addition to the group ranches, Kirisia forest is closely associated with Maralal town which is the administrative centre for Samburu County. The town is situated within the forest reserve and has a cosmopolitan population comprising of the Samburus and other ethnic communities including the Kikuyu, Meru, Somali and Turkana [34]. Most of the local people in the Kirisia region are pastoralists although mixed agriculture-livestock livelihood practices are common in the humid areas to the north such as Porror where wheat, maize and other crops are grown [23] [24]. Kirisia Forest is central to all the various communities in the area because it sustains their socio-economic aspirations by providing diverse goods and services including but not limited to dry season livestock grazing areas and watering sites, construction materials, honey, herbal medicine and wood-fuel among others [22] [24] [34]. The extraction of such goods is likely to significantly affect the land cover status of the forest thereby affecting the long term delivery of ecosystem services.

\section{Methods}

Remote sensing and GIS techniques were used to analyze and characterize land cover change in Kirisia Forest through various steps which included: 1) delineation of watershed ecosystem boundary; 2) satellite land cover change analysis and ground truthing; 3) comparative analysis with other land cover studies. The watershed boundary was delineated from medium resolution $(30 \times 30 \mathrm{~m})$ Landsat images and ASTER Digital Elevation Model (DEM) using the ArcGIS 10.3 software. The 30m spatial resolution Landsat images were considered to be detailed enough for the purpose of land cover status and change analysis. The images were identified by overlaying the delineated watershed boundary in the Landsat image grid with subsequent selection of the images that covered the study area, namely P169R059, P168R059 and P168R060 as shown in Figure 2.

Twelve Landsat images were acquired and then processed by mosaicking them into a single image for each of 


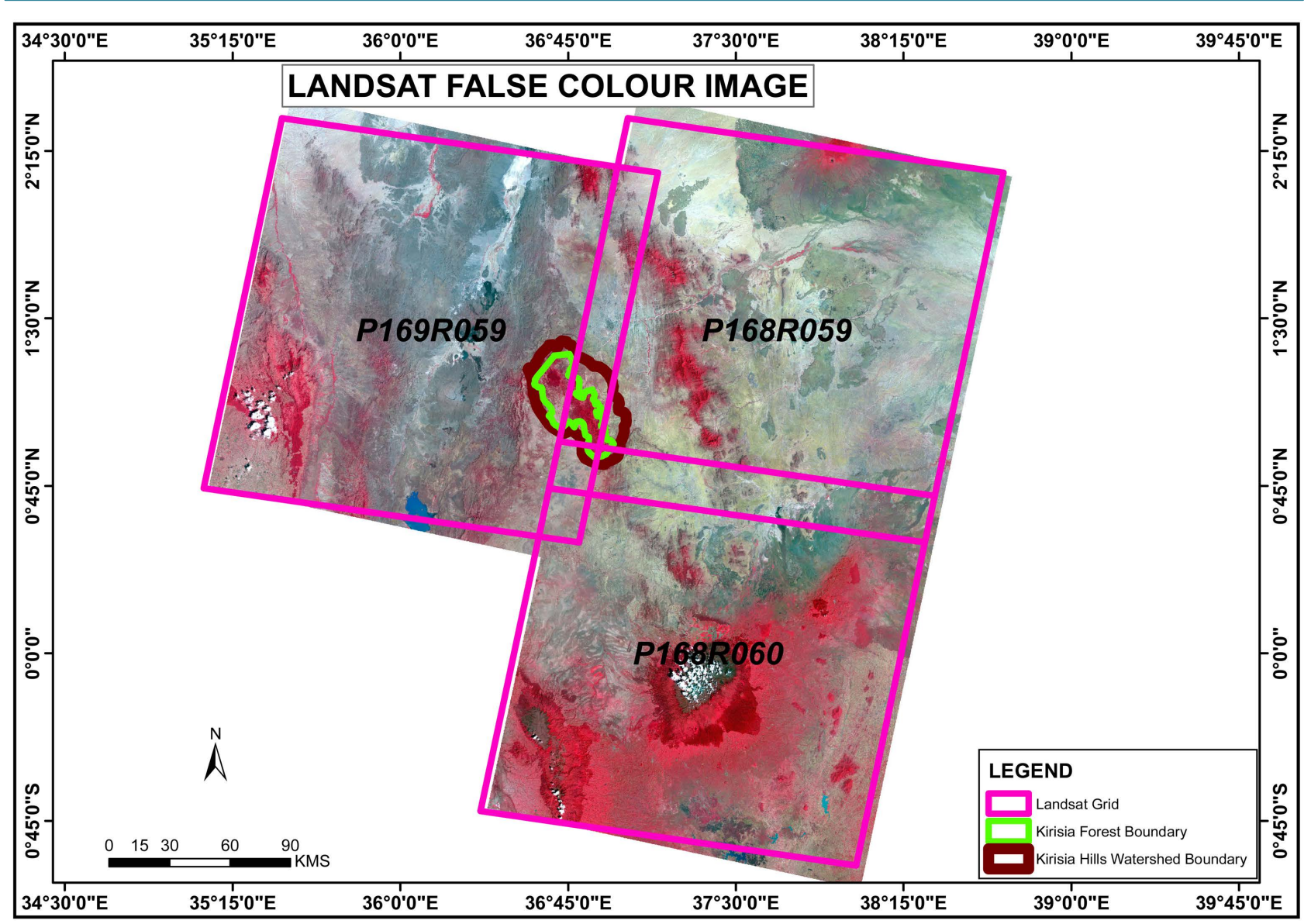

Figure 2. False colour composite images for the Kirisia forest region.

the four years with less than 10\% cloud cover, namely 1973, 1986, 2000 and 2015. Thereafter, colour composite images were processed for land cover interpretation and analysis with the aid of ground-truth information. The land cover ground truthing was undertaken through field inspection missions undertaken in October and November 2015. The ground truthing was conducted through four inspection transects, namely: 1) Maralal-Engata-Nanyukie transect $(45 \mathrm{~km})$ on $30^{\text {th }}$ October $\left.2015 ; 2\right)$ Mararal-Ngari-Baawa transect (31 km) on $31^{\text {st }}$ October 2015; 3) Maralal-Opiroi transect (16 km) on $31^{\text {st }}$ October 2015 ; 4) the Maralal-Ngonyeki transect $(10 \mathrm{~km})$ on $1^{\text {st }}$ November 2015. Most of the inspection points in Transects 1 and 2 were located at the edge of Kirisia Forest while those in Transects 3 and 4 were traversing through the forest in easterly and northerly orientations from Mararal town. Figure 3 shows the GPS points for the 42 observation points in the four inspection transects.

The land cover inspections involved a drive-through along each of the four transects with observation stops at different points based on landscape and land-cover change. The elevation in each observation point was recorded using a Garmin GPS unit. In addition, rapid appraisal of the dominant land cover type was undertaken and the key woody plant species identified. The specimen of the species which could not be identified on site were clipped and preserved in a plant press and later identified at the herbarium in the School of Biological Sciences at University of Nairobi. The final image interpretation was undertaken using the ground truth information which entailed the downloading of the field GPS points, overlaying them on the satellite images and then undertaking preliminary image classification using ArcGIS 10.3. The polygons were digitized on the satellite images around the overlaid GPS points for areas with homogeneous spectral reflectance from which the land cover classes were generated. Once the classification around all the GPS points was completed, the classification was then extrapolated to the other parts of the watershed. Thereafter, the total area under each land cover type was calculated in square kilometers followed by land cover change detection for 1973, 1986, 2000 and 2015. All the analysis was done using the IDRISI land cover change modeler which also employs cross-tabulation to produce 
F. Warinwa et al.

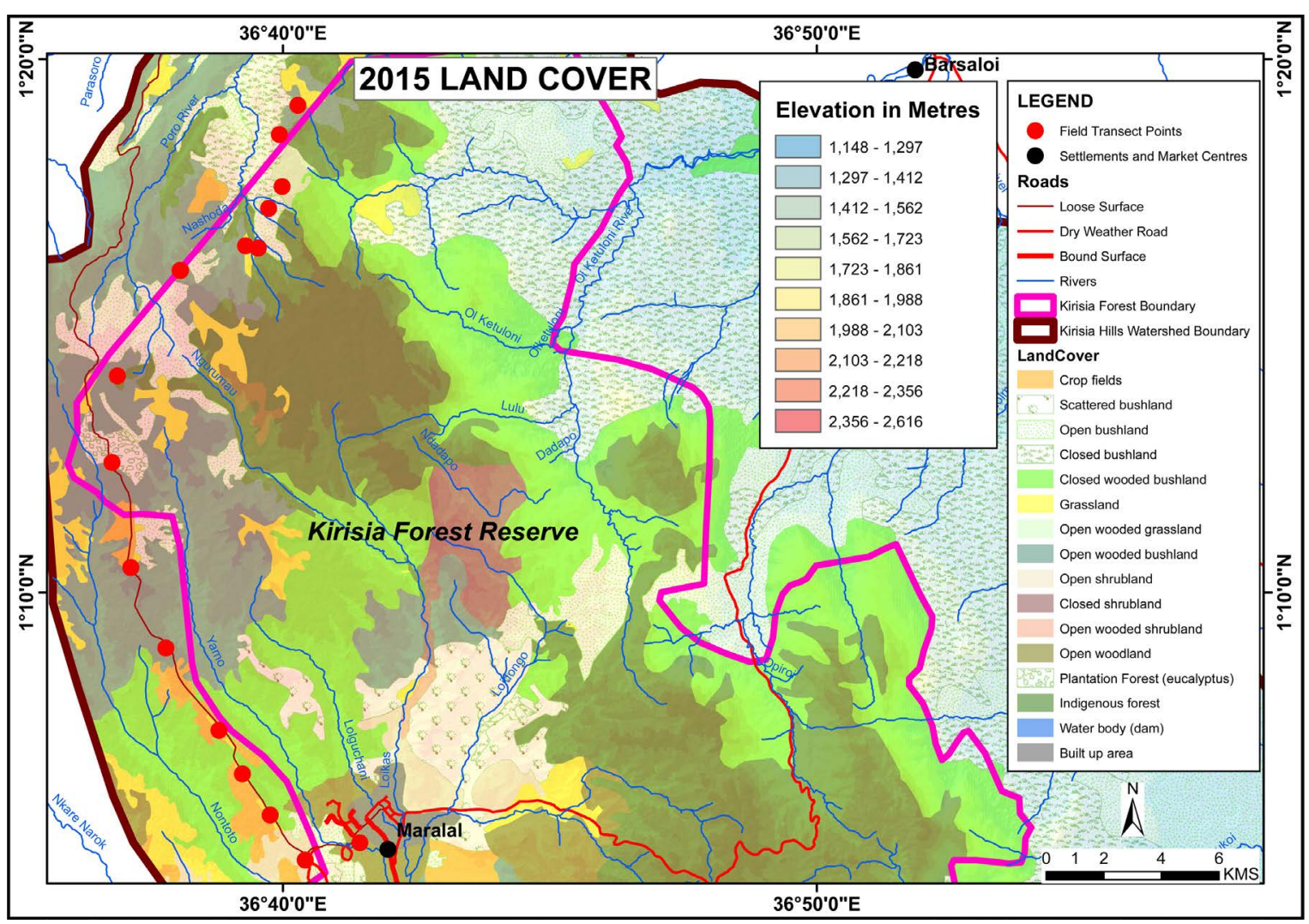

(a)

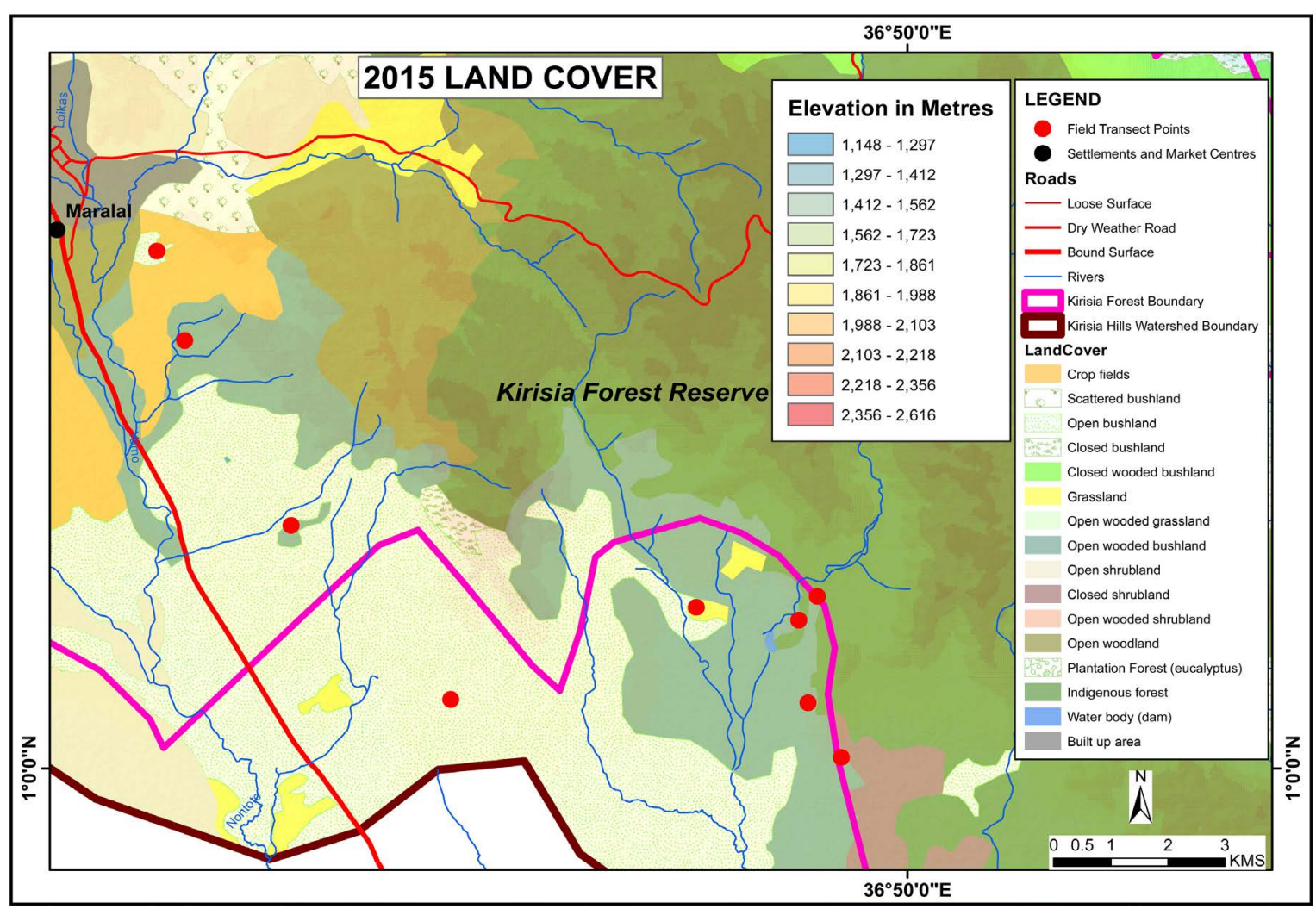

(b) 


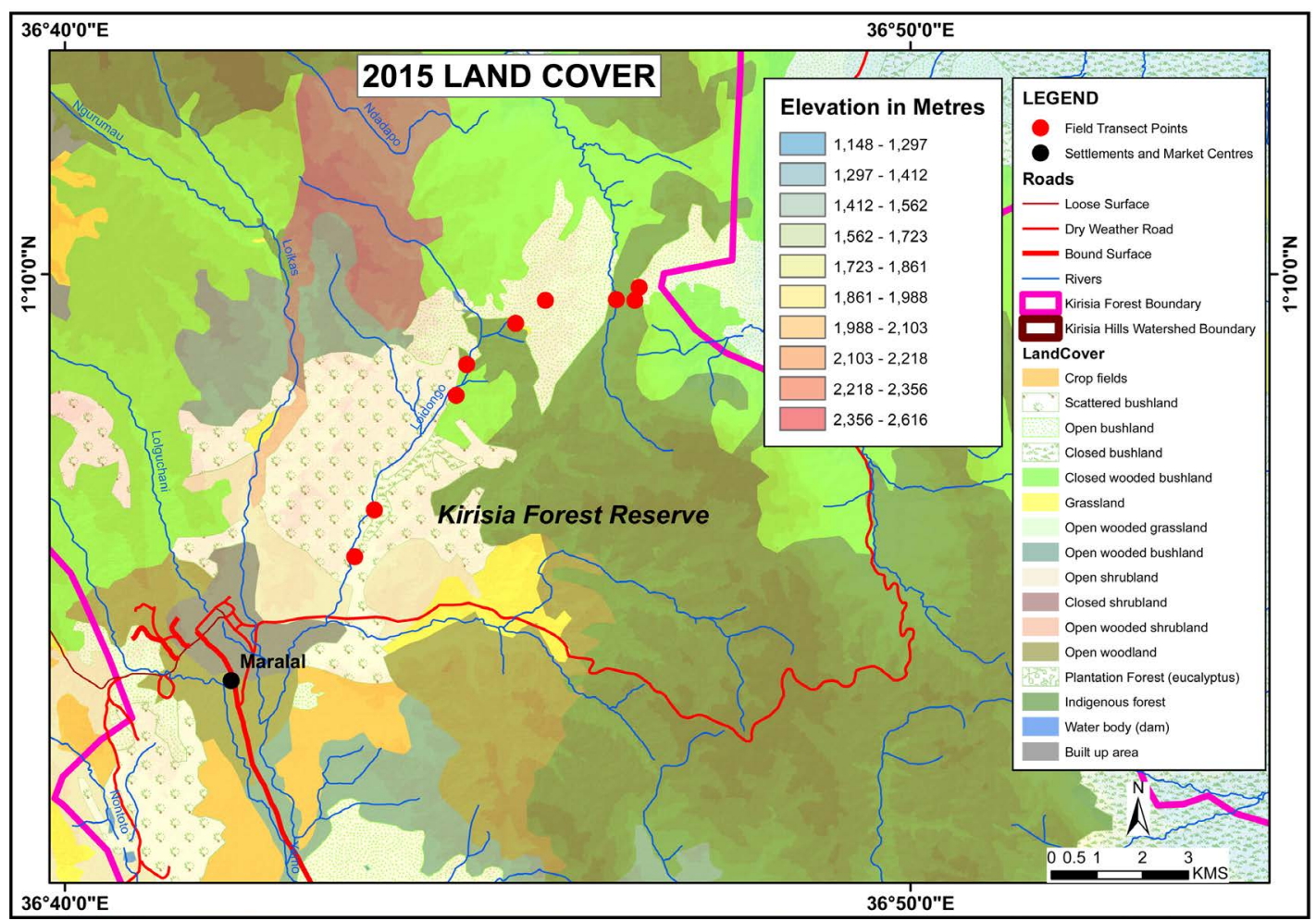

(c)

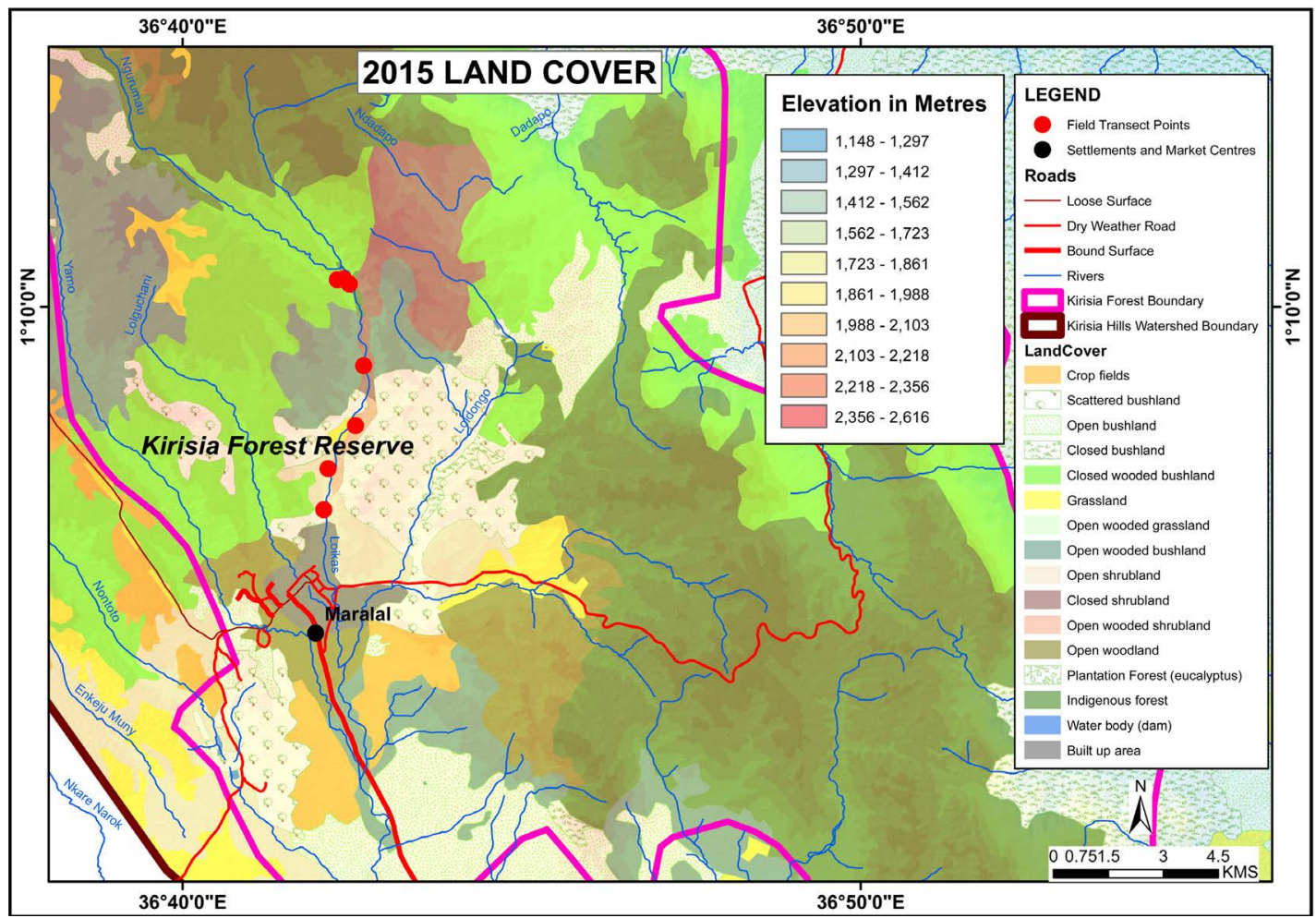

(d)

Figure 3. The route and GPS points for the four land cover ground truthing inspection transects. (a) Transect 1-Maralal-engata-nanyukie transect (45 km). (b) Transect 2-Mararal-Ngari-Baawa transect (31 km). (c) Transect 3-Maralal-Opiroi transect (16 km). (d) Transect 4-Maralal-Ngonyeki transect (10 km). 
land cover change maps and area statistics.

\section{Results and Discussion}

Land cover ground truth inspection in the northern section (transect 1) showed that the Lpartuk area was previously dominated by a dense Juniperus-Olea evergreen forest but this had now been converted into human settlements and farmlands. A large plantation of Eucalyptus globulus covering approximately $3 \mathrm{~km}^{2}$ had also been established in Porror area. The forest section near the Samburu air flight radar was found to be relatively intact and dominated by Juniperus procera, Olea Africana, Olinis rocheatina, Clutia abyssinica, Trimeria grandifolia, and Rhus natalensis. Some remnants of the sandalwood (Osyris lanceolata) were also recorded in that section. In the Ngorika area, large sections of the forest were destroyed by wildfires in the 1980s and were yet to recover partly because the area had been encroached by illegal squatters. The riparian area along the Nachuda stream was dominated by Juniperus procera, Podocapus, Olea Africana and Vepris simpicifolia and was heavily utilized by elephants.

The southern section of the forest in the Baawa area (transect 2) was dominated by Croton megalocarpus, Acacia xanthopholea, Juniperus procera, Olea Africana, Vepris simplicifolia, Akakanthera schimperi and Euclea divinorum. This part of the forest was characterized by intensive use by the locals through domestic water abstraction, livestock grazing and the watering especially in the dry seasons. The area was also heavily used by elephants and other wildlife especially common zebra (Equus burchelli boehmi), Thompson gazelle (Gazella thomsonii) and impala (Aepyceros melampus).

The central sections of the forest especially to the east of Mararal town (transect 3) was the most degraded probably because of its close proximity to Mararal town. Most of the area had been converted from the previously dense evergreen forest to evergreen Euclea divinorum shrub. Most of the giant Olea africana trees had been chopped off to provide forage for the livestock especially in the dry season while the Juniperus procera had been logged for commercial house construction and household fencing posts. Active and widespread charcoal burning of Olea africana was recorded along the Lorok riparian zone which was also characterized by intensive livestock grazing. The Ngonyeki section of the forest to the north-east of Mararal town (transect 4) was found to be largely intact and dominated by Olea Africana, Juniperus procera, Croton megalocarpus, and Podocarpus sp trees as well as Rhus natalensis and Euclea divinorum shrubs. This part of the forest was also heavily utilized by elephants.

Table 1 shows the land cover change statistics based on satellite imagery analyses for 1973, 1986, 2000 and 2015 whose land cover maps are shown in Figure 4. Figure 5 shows the integrated land cover change pattern for the 1973-2015 period. The dominant land cover types during this 42-year period comprised natural or indigenous forest, followed by shrub land, bush land and built environment consisting of urban areas and other human settlements. The results showed a major increase in the built environment by about $55.4 \%$, and a significant decrease in forest cover by $21.3 \%$. Upto $83.9 \mathrm{~km}^{2}$ of the original indigenous forest was lost between 1973 and 1986 due to severe fire in the 1980s. The forest fires are said to have occurred in 1984 and 1996 in protest following the eviction by the government of illegal squatters in the forest. Such severe fires are environmentally very destructive because they destroy mature trees which have taken many years to grow in a semi-arid area and also hamper forest regeneration by killing the saplings. They can also alter the composition of woody species with more fire tolerant species becoming more dominant.

Thereafter, $23.7 \mathrm{~km}^{2}$ of the remaining indigenous forest was lost between 1986 and 2000 mainly through charcoal burning, illegal timber logging and livestock forage harvesting. A slight recovery occurred between 2000 and 2015 with a 5\% increase in indigenous forest cover mostly through natural succession by shrub land and bush land in the burnt areas especially following the $1998 \mathrm{El}$ Nino period. Between 1973 and 2015, Kirisia forest experienced a huge expansion in grassland, shrub land and bush land mostly due to the ecological impacts of the wildfires of 1984 and 1996 also coupled by the increased degradation of the forest as indicated by the reduction in natural forest cover. The prevalence of these land cover types is an indicator that human activities in the forest as well as climate change are gradually transforming the ecosystem in a negative way.

The findings showed the conversion of some sections of natural forest into Eucalyptus plantation in the Porror area. The ground truth information indicated that a similar plantation had been established in the Angata Nanyokie area in the 1940's. The satellite image analysis showed that the Porror Eucalyptus plantation expanded by approximately $1.7 \mathrm{~km}^{2}$ between 1986 and 2000 and thereafter declined by $0.3 \mathrm{~km}^{2}$ in 2015 due to intentional 
Table 1. Landcover change statistics for the Kirisia Forest (1973-2015).

\begin{tabular}{|c|c|c|c|c|c|c|c|c|}
\hline \multirow{2}{*}{ Land cover type } & \multicolumn{4}{|c|}{ Area in $\mathbf{k m}^{2}$} & \multirow{2}{*}{$\begin{array}{c}\text { Overall change } \\
\text { (1973-1986) }\end{array}$} & \multirow{2}{*}{$\begin{array}{c}\begin{array}{c}\text { Overall } \\
\text { change }\end{array} \\
(1986-2000)\end{array}$} & \multirow{2}{*}{$\begin{array}{c}\begin{array}{c}\text { Overall } \\
\text { change } \\
(2000-2015)\end{array} \\
\end{array}$} & \multirow{2}{*}{ \% Change } \\
\hline & 1973 & 1986 & 2000 & 2015 & & & & \\
\hline Indigenous forest & 430.6 & 346.7 & 322.9 & 338.8 & -83.9 & -23.7 & 15.8 & -21.3 \\
\hline Plantation forest & 0.0 & 1.6 & 3.2 & 2.9 & -1.6 & 1.7 & -0.3 & 57.0 \\
\hline Open woodland & 23.0 & 52.4 & 60.8 & 55.5 & -29.3 & 8.4 & -5.3 & 58.6 \\
\hline Wooded shrub land & 1.0 & 1.0 & 1.1 & 0.9 & 0.1 & 0.1 & -0.2 & 16.9 \\
\hline Closed shrub land & 416.4 & 18.2 & 19.3 & 19.1 & 398.3 & 1.1 & -0.2 & 95.4 \\
\hline Open shrub land & 67.1 & 35.2 & 35.2 & 35.4 & 31.8 & -0.1 & 0.2 & 47.2 \\
\hline Wooded bush land & 70.6 & 152.1 & 151.3 & 151.5 & -81.5 & -0.8 & 0.2 & 53.4 \\
\hline Wooded grassland & 0.0 & 1.8 & 1.9 & 1.8 & -1.8 & 0.2 & -0.2 & 100.0 \\
\hline Open grassland & 72.9 & 91.6 & 91.4 & 92.9 & -18.7 & -0.2 & 1.6 & 21.6 \\
\hline $\begin{array}{l}\text { Closed wooded bush } \\
\text { land }\end{array}$ & 29.9 & 209.9 & 218.6 & 209.9 & -179.9 & 8.7 & -8.7 & 85.7 \\
\hline Closed bush land & 339.9 & 451.7 & 454.9 & 455.8 & -111.7 & 3.2 & 0.9 & 25.4 \\
\hline Open bush land & 290.6 & 323.1 & 323.3 & 322.4 & -32.5 & 0.3 & -1.0 & 9.9 \\
\hline Scattered bush land & 17.3 & 52.3 & 52.6 & 49.8 & -35.0 & 0.3 & -2.9 & 65.3 \\
\hline Crop fields & 0.0 & 19.5 & 20.2 & 19.4 & -19.5 & 0.7 & -0.7 & 100.0 \\
\hline Water body (dams) & 0.1 & 0.3 & 0.3 & 0.3 & -0.1 & 0.0 & 0.02 & 60.4 \\
\hline Built up area & 2.5 & 4.8 & 5.0 & 5.6 & -2.3 & 0.2 & 0.6 & 55.4 \\
\hline
\end{tabular}

harvesting by KFS which was eventually resisted by the local people.

Table 1 shows a massive build-up in human settlements within the watershed due to human population growth and urbanization in Maralal and other towns such as Kisima and Suguta Marmar which have attracted immigrants from other parts of Kenya. It was established that human population growth has significantly contributed towards the land cover change in Kirisia forest. Most of the communities in Samburu County are embracing sedentary lifestyles instead of nomadic pastoralism. This has seen most people constructing modern permanent houses which consume a lot of wood thereby decimating indigenous tree species especially Juniperus procera. The increased harvesting of subsistence and commercial timber as well as firewood gathering and illegal charcoal burning have also continued to degrade the forest ecosystem.

The findings in this study indicated a lower level of forest reduction at $21.3 \%$ compared to the estimates of [35], who recorded a 46\% reduction in the wider Samburu County for the 1976-2000 period, although his work was focussed on the Mathew Ranges and Ndotto forest. The reduction in Kirisia forest cover was almost similar to the decline in the Chyulu Hills where [12] estimated an $18.6 \%$ decline in natural forest mostly through the negative impact of frequent wildfires. The 1984 and 1996 fires in Kirisia forest caused massive damage to the ecosystem and the effects were still visible during this study. According to [36], Africa leads the world in terms of the annual number of forest wildfires. In 2000 it was estimated that 1.75 million $\cdot \mathrm{km}^{2}$ of forest, woodlands, and grasslands which constituted about 5.8\% of Sub-Saharan Africa was lost through such fires. Most of the fires were intentionally started in order to clear land for agricultural cultivation [36].

In Kenya, up to 40\% of all the wildfires which occurred between 1990 and 2010 were associated with arson, $20 \%$ to negligence and carelessness and $40 \%$ due to unknown causes [37]. Unintentional fires in the country are also associated with honey gatherers during the smoking of bees in forests. Apart from loss of biodiversity, forest fires have a significant negative hydrological impact because loss of forest cover reduces the natural recharge capacity and increases flood hazards, surface erosion and siltation of rivers and water bodies. Previous studies have confirmed that frequent forest fires can have significant impact on watershed hydrology. [37] reported a 66\% reduction in infiltration rate within a pine forest area in Arizona which initially resulted in an $800 \%$ increase in stream flow from the burnt catchment immediately after the fire. This means that forest fires will tend to increase the risk of flood hazards during the wet season and exacerbate the problem of water scarcity in the dry 
F. Warinwa et al.

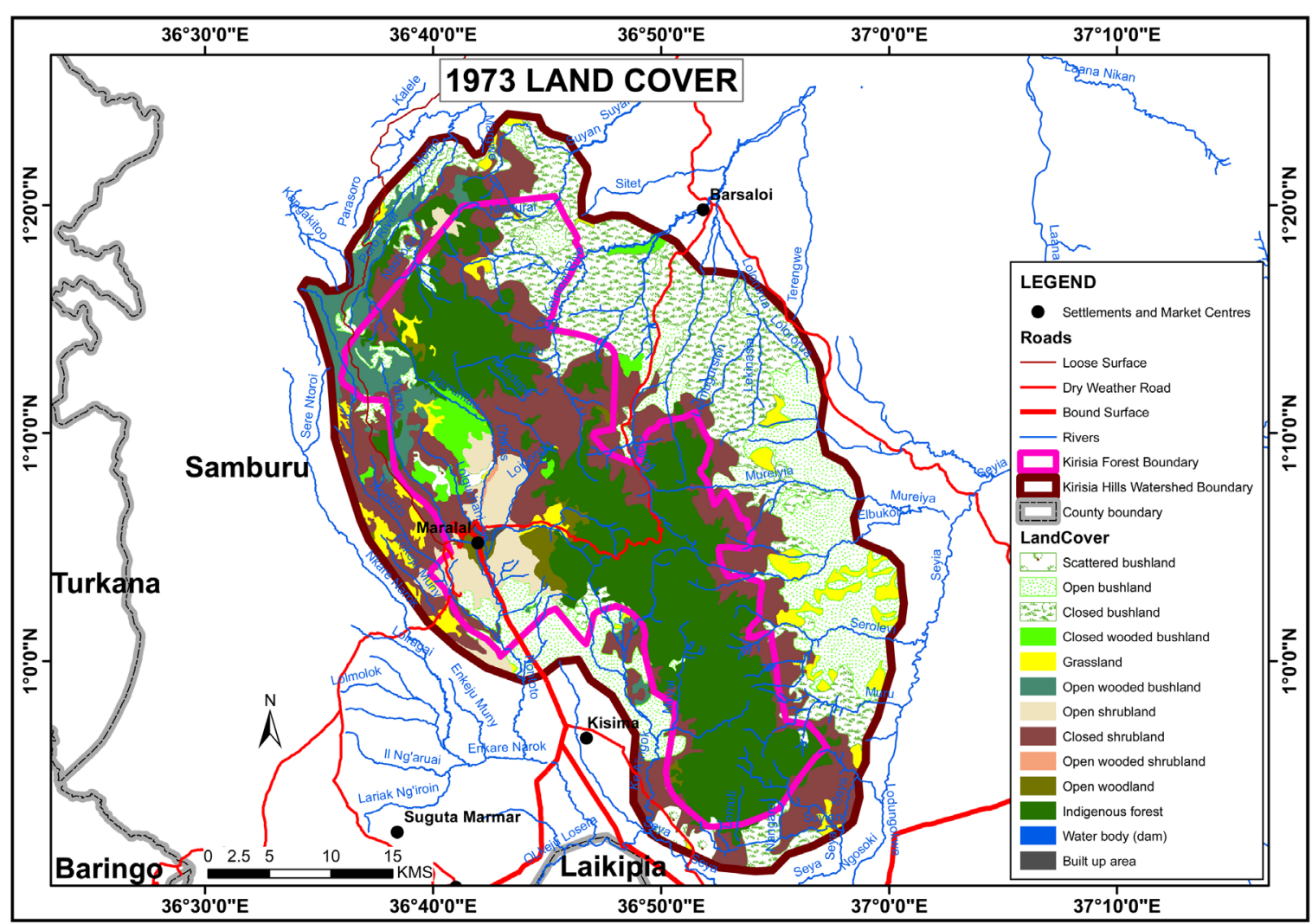

(a)

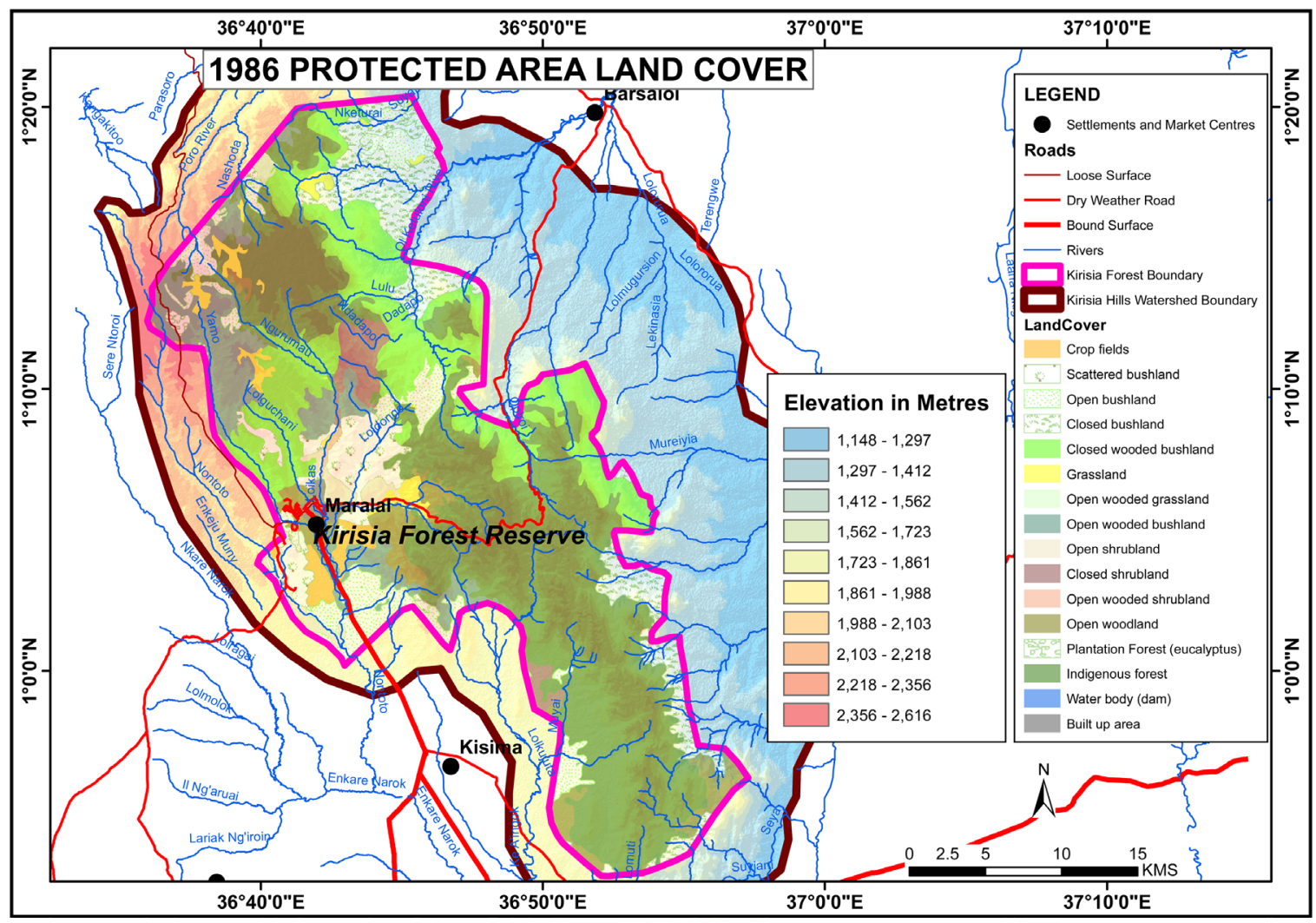

(b) 


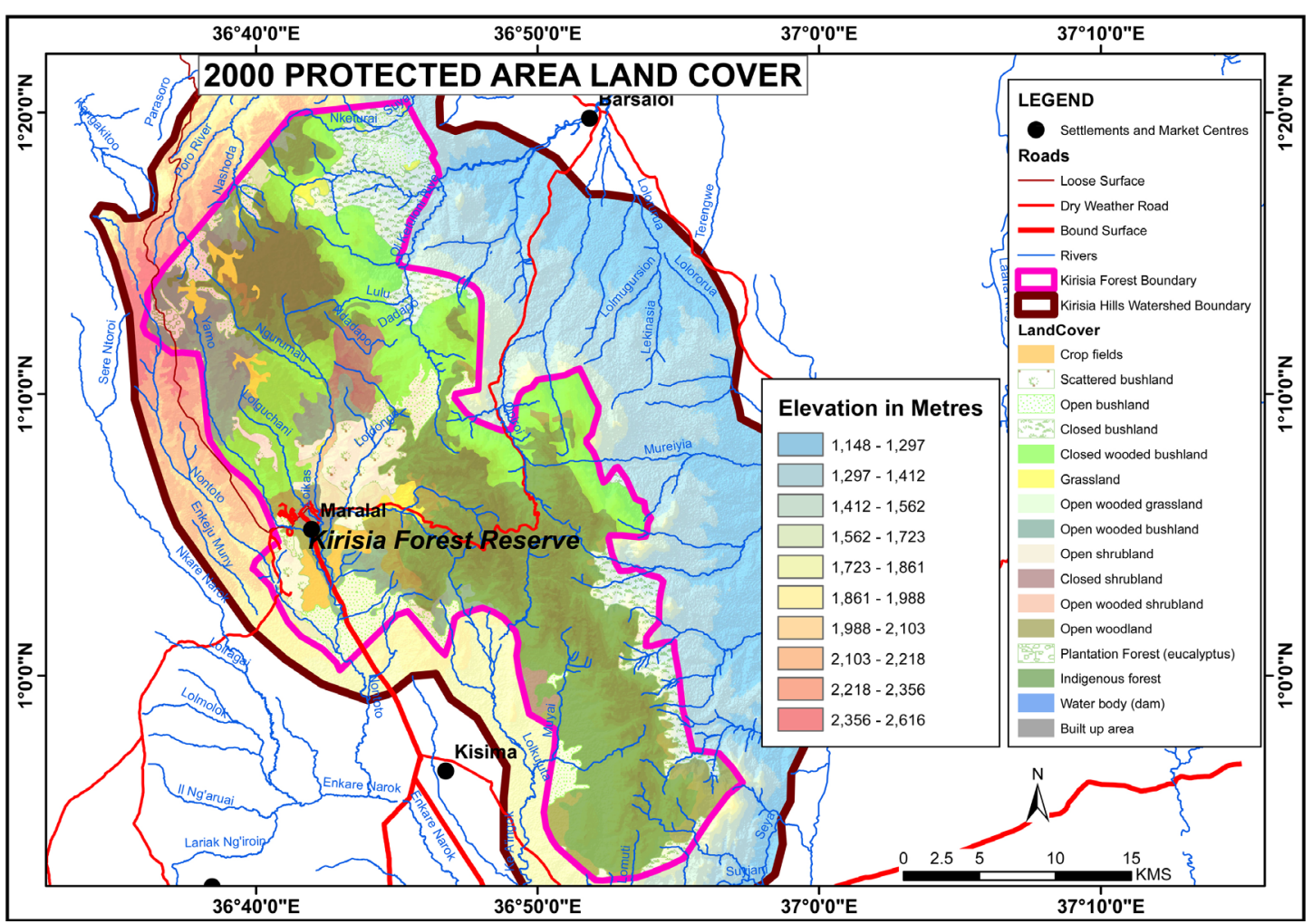

(c)

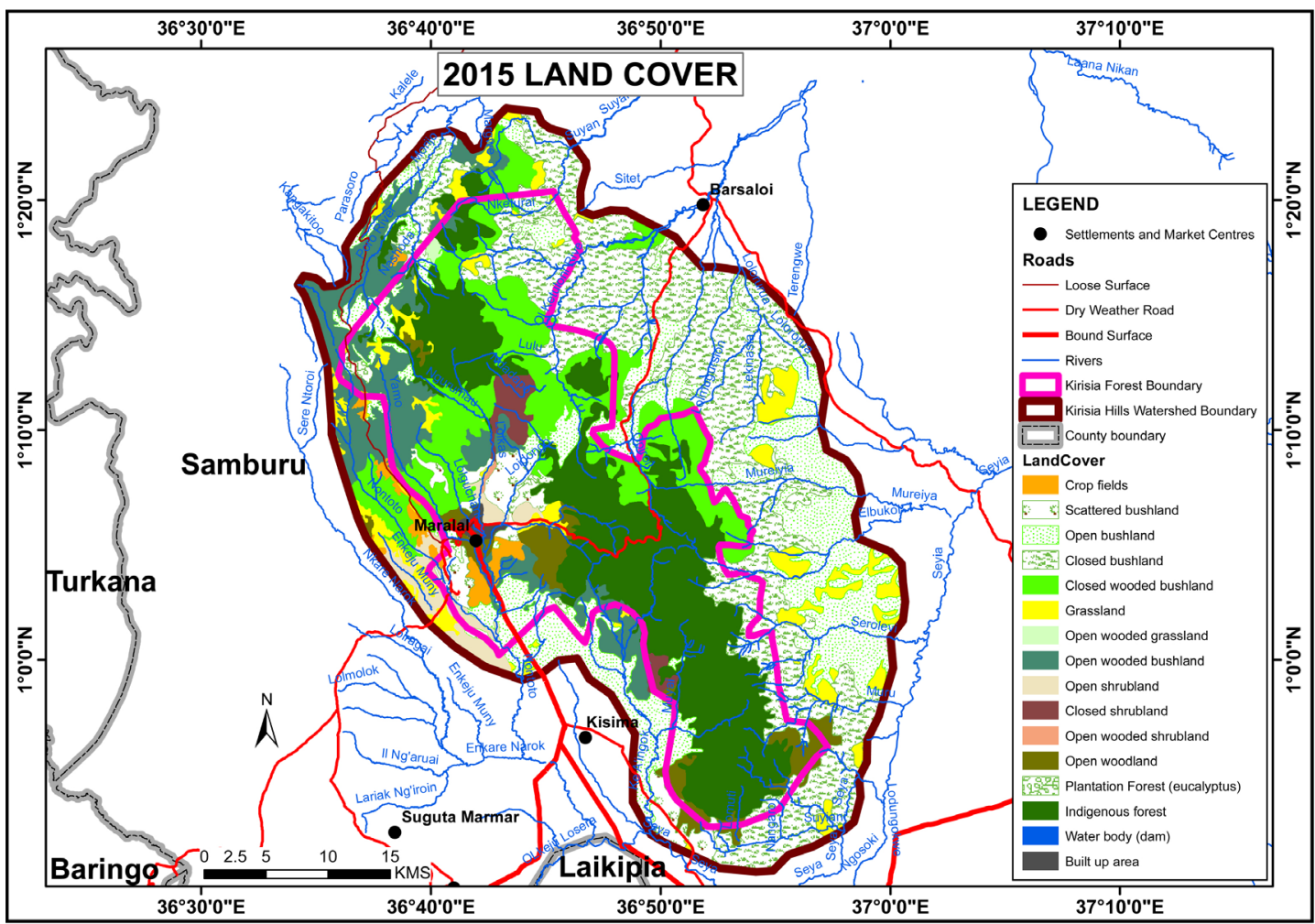

(d)

Figure 4. Land cover change in Kirisia forest (1973-2015). (a) Kirisia forest cover in 1973. (b) Kirisia forest cover in 1986. (c) Kirisia forest cover in 2000. (d) Kirisia forest cover in 2015. 


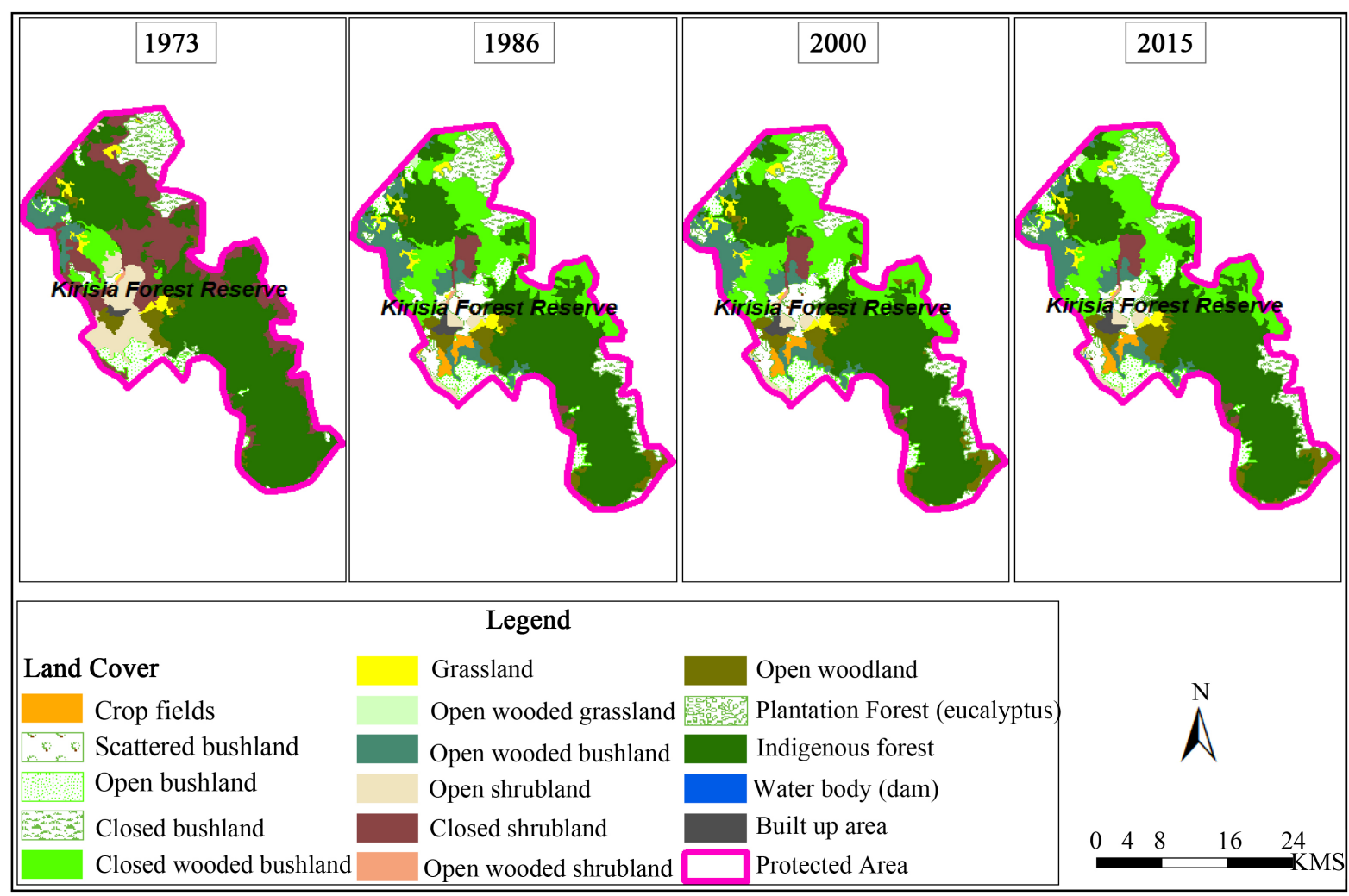

Figure 5. Integrated land cover change for the Kirisia forest watershed (1973-2015).

season due to the low recharge capacity induced by the loss of forest cover.

The rate of forest cover loss in Kirisia Forest was much lower than the 32\% decline recorded by [15] in Marsabit Forest between 1973 and 2005 during which upto $58.6 \mathrm{~km}^{2}$ of forest was lost. Both Marsabit and Kirisia Forest are dryland water towers with very similar status in terms of their location within rapidly expanding urban centers which are both county headquarters. However, Marsabit forest is under more strict protection because of its designation as a national park under the Kenya Wildlife Service (KWS) and would therefore be expected to experience a lower rate of forest loss. The difference might be attributed to differences in the urban population growth in the two towns. While Mararal town has an estimated population of 20,000, the current population estimate for Marsabit town is about 30,000 people which translate to a much higher demand for a wide range of forest resources. The lower rate of forest loss in Kirisia Forest can also be attributed to the concerted efforts by the Kirisia Community Forest Association (KCFA) which provides a critical platform for participatory forest management (PFM) for the forest reserve although it is facing serious resistance by the people including local politicians. On the overall, it is evident that rural communities are negatively impacting forest ecosystems thereby jeopardizing their natural water supply which is more critical in comparison to other society needs. This pattern is common in many other parts of Kenya [38]-[43].

\section{Conclusions and Recommendations}

The loss of forest cover in the Kirisia watershed ecosystem between 1973 and 2015 was enormous but quite similar to the challenging situation in other valued watershed ecosystems around the country including the national water towers. The $21.3 \%$ reduction in forest cover within the watershed is unfortunate because it will eventually affect the role of the watershed as a critical dryland water tower. The findings clearly showed that the watershed ecosystem was experiencing negative forest cover dynamics despite the efforts by government and remarkable grass root effort through the CFA to safeguard the forest. The main reason for the negative land cover change in the watershed ecosystem is lack of public awareness and appreciation of the need to maintain a good state of forest ecosystem health in order to continue enjoying the watershed ecosystem services. This fact is usually taken for granted until it is too late. With declining forest cover, the hydrological functions of the wa- 
tershed ecosystem will be impaired leading to increased water scarcity especially in Mararal town and its environs. Maralal town is currently rated as among the fastest growing in Kenya with a growth rate of about $7 \%$ per annum. The water demand in Mararal is likely to increase significantly as a result of the Lamu Port South Sudan Ethiopia Transport (LAPSSET) corridor project and the on-going tarmacking of the Rumuruti-Mararal Highway both of which will attract more investors into the town.

Although the major loss of forest cover in Kirisia Forest was attributed to the massive fires of 1980s and 1990s, substantial forest loss had continued to occur through illegal logging, charcoal burning, and harvesting of livestock fodder. Consequently, a combination of strategies is needed to halt or reduce further loss. These include the following:

- Initiating more meaningful collaboration between Samburu County Government and other key stakeholders especially the Kirisia Forest CFA, Kenya Forest Service (KFS), Kenya Wildlife Service (KWS), Kenya Water Towers Agency (KWTA) and Water Resources Management Authority (WRMA) for more effective conservation and restoration of the forest ecosystem. This effort should focus on creating awareness among various forest users on the linkage between forest cover change and water supply so that the stakeholders can appreciate and support forest conservation efforts in a more serious way.

- Controlling the increasing problem of illegal logging and charcoal burning in the forest by enforcing the Forest (Charcoal) Regulations (2009). The regulations are enacted by the government in order to enable the KFS to regulate the production, transportation and marketing of forest products and ensure sustainable use of forests. The strict enforcement of these regulations may reduce the rapid loss of valued species such as Olea africana in the forest.

- Regulating livestock grazing and harvesting of fodder in the forest by educating the local communities on the need to reduce their livestock herds. Effective and negotiated forest use guidelines for livestock grazing in the forest should also be put in place with a view of reducing livestock incursion into the forest including the disturbance of key water sources.

- Developing participatory fire prevention and control strategies especially for CFA members and educating neighboring communities (and honey harvesters) on the environmental hazards associated with forest fires.

- Supporting the implement the Kirisia Forest Management Plan which was developed in 2012 but has not been effectively actualized.

\section{Acknowledgements}

The funding was provided by the African Wildlife Foundation (AWF) for which special appreciation goes to the County Director Ms. Fiesta Warinwa for her support and great ideas. The remarkable technical support provided by WRMA through David Mumo, Kimeu Musau, John Kinyua and Inoti Mburugu is appreciated. Many thanks also for the support, advice and valuable information provided by the Samburu County Director of Environment, Water and Natural resources Mr. Benson Lengalen and the Managing Director of SAWASCO Mr. Mark Lcharuni. The Vice-secretary of the Kirisia Forest Community Forest Association Mr. Wilson Lekaaso was the field guide and liaison for the research team and his instrumental support is highly appreciated. Finally, many to Ms. Tiffany Mwake of Habitat Planners for providing incredible support in terms of information gathering, documentation and manuscript typesetting in addition to running many other errands.

\section{References}

[1] Scudder, T. (1971) Gathering among African Woodland Savannah Cultivators: A Case Study of the Gwembe Tonga. Manchester University Press for the University of Zambia, Institute for African Studies, Lusaka.

[2] Food and Agriculture Organization (FAO) (2011) Forests for Improved Nutrition and Food Security. Food and Agriculture Organization of the United Nations. Rome.

[3] African Development Bank (AfDB) (2015) Payment for Environmental Services; a Promising Tool for Natural Resources Management in Africa. Environment and Climate Change Department (ONEC), African Development Bank, Abidjan.

[4] Maghembe, J.A., Kwesiga, F., Ngulube, M., Prins, H. and Malaya, F.M. (1994) Domestication Potential of Indigenous Fruit Trees of the Miombo Woodlands of Southern Africa. In: Leaky, R.R.B. and Newman, A.C., Eds., Tropical Trees: Potential for Domestication and Rebuilding of Forest Resources, Her Majesty’s Stationery Office, London.

[5] Ministry of Environment and Natural Resources (MENR) (1994) Kenya Forestry Master Plan. Nairobi, Kenya. 
[6] Wass, P. (1995) Kenya’s Indigenous Forests: Status, Management and Conservation. Gland.

[7] National Environment Management Authority (NEMA) (2013) Mau Complex at a Glance. NEMA, Nairobi.

[8] Mogaka, H.R. (2000) Economic Analysis of Forest Resource Values to Local Communities in Kenya: Comparative Study Cases of Kakamega and Ntugi-Kijege Reserves. PhD Thesis, University of Strathclyde, Glasgow.

[9] Nkako, F.M., Lambrechts, C., Gachanja, M. and Woodley, B. (2005) Mau Forest Status Report. UNEP, Nairobi.

[10] Government of Kenya (GoK) (2009) Rehabilitation of the Mau Forest Ecosystem. A Project Concept Prepared by the Interim Coordinating Secretariat, Office of the Prime Minister, on Behalf of the Government of Kenya.

[11] Kenya Forest Service (KFS) (2011) Sururu Participatory Forest Management Plan: 2011-2015.

[12] Kiringe, J.W., Mwaura, F. and Kimeu, M.M. (2015) Watershed Ecosystem Services and Water Management Tools” for the Kirisia Forest Ecosystem in the Samburu Landscape. Report to the African Wildlife Foundation (AWF), Nairobi.

[13] GoK (2013) Analysis of Drivers and Underlying Causes of Forest Cover Change in the Various Forest Types of Kenya. Ministry of Forestry and Wildlife, Nairobi.

[14] Ayuyo, I.O. and Sweta, L. (2014) Land Cover and Land Use Mapping and Change Detection of Mau Complex in Kenya Using Geospatial Technology. International Journal of Science and Research (IJSR), 3, 767-778.

[15] Oroda, A.S.K. (2011) The Impact of Increased Population and Sedentarization of the Pastoral Communities on the Land Cover and the Resources of Mount Marsabit Forest and the Surrounding Lands. Master of Environmental Sciences Thesis, Kenyatta University, Nairobi.

[16] Bytebier, B. (2001) Taita Hills Biodiversity Project Report. National Museums of Kenya, Nairobi.

[17] Pellikka, P.B., Clark, P., Hurskainen, A., Keskinen, M., Lanne, K., Masalin, P., Nyman-Ghezelbash, P. and Sirviö, T. (2004) Land Use Change Monitoring Applying Geographic Information Systems in the Taita Hills, SE-Kenya. Proceedings of the 5th African Association of Remote Sensing of Environment Conference, Nairobi, 17-22 October 2004.

[18] Karanja, A., China, S.S. and Kundu, P.M. (1986) The Influence of Land Use on the Njoro River Catchment between 1975 and 1985. Soil and Water Conservation in Kenya, University of Nairobi, Nairobi, Kenya.

[19] Donner, D.S. (Ed) (2004) Land Use, Land Cover, and Climate Change across the Mississippi Basin: Impacts on Selected Land and Water Resources. American Geophysical Union, 249-262.

[20] Mustafa Y.M., Amin, M.S.M., Lee, T.S. and Shariff, A.R.M. (2005) Evaluation of Land Development Impact on a Tropical Watershed Hydrology Using Remote Sensing and GIS. Journal of Spatial Hydrology, 5, 16-30.

[21] Marloes, L.M. (2009) Understanding Hydrological Processes in an Ungauged Catchment in Sub-Saharan Africa. PhD Thesis, UNESCO-IHE and Delft University of Technology, Delft.

[22] Watai, M.K. and Gachathi, F. (2003) Conservation for Sustainable Utilization of Biodiversity through Enhanced Access and Benefit Sharing with Forest Adjacent Communities in Kirisia Forest Samburu District. Unpublished Report, KFS, Nairobi.

[23] Hitimana, J., Kiyiapi, J., Kisioh, H., Warinwa, F., Lenaiyasa, P., Kibugi, P., Mayienda, R. and Sumba, D. (2005) Linking Socio-Economic Significance and Conservation for Kirisia Forest, Samburu, Kenya. Technical Paper to African Wildlife Foundation (AWF), Nairobi.

[24] Anne, P. (2009) Preliminary Ecological Survey of Kirisia Forest Reserve, Samburu District. Report to Laikipia Wildlife Forum for Conservation Enterprise Development Program.

[25] Powys, A. (2009) A Preliminary Ecological Survey of Kirisia Forest Reserve, Samburu District for Conservation Enterprise Development Program. Unpublished Report, AWF, Nairobi.

[26] Czajkowski, K. and Lawrence, P.L. (2013) GIS and Remote Sensing Applications for Watershed Planning in the Maumee River Basin, Ohio. Springer Science + Business Media, Dordrecht.

[27] Butt, A., Shabbir, R., Ahmad, S.S. and Aziz, N.N. (2015) Land Use Change Mapping and Analysis Using Remote Sensing and GIS: A Case Study of Simly Watershed, Islamabad, Pakistan. The Egyptian Journal of Remote Sensing and Space Science, 18, 251-259. http://dx.doi.org/10.1016/j.ejrs.2015.07.003

[28] Rawat, J.S. and Kumar, M. (2015) Monitoring Land Use/Cover Change Using Remote Sensing and GIS Techniques: A Case Study of Hawalbagh Block, District Almora, Uttarakhand, India. The Egyptian Journal of Remote Sensing and Space Science, 18, 77-84. http://dx.doi.org/10.1016/j.ejrs.2015.02.002

[29] Nyaligu, M.O. (2013) Water Resources Inventory and Assessment, Kirisia Forest National Reserve. Final Report to African Wildlife Foundation (AWF), Nairobi.

[30] Jaetzold, R. and Schmidt, H. (1983) Farm Management Handbook Vol. II-Natural Conditions and Farm Management Information, Part B Central Kenya (Rift Valley and Central Provinces). Ministry of Agriculture, Kenya, in Cooperation with the German Agricultural Team (GAT) of the GTZ, Nairobi. 
[31] Beentje, H.J. (1990) The Forests of Kenya. Mitteilungen aus dem Institut für 14. Allgemeine Botanik in Hamburg, 23a, 265-286.

[32] Evans, M.I. and Fishpool, L.D.C. (2001) Important Bird Areas in Africa and associated Islands: Priority Sites for Conservation. Birdlife International, Pisces Publications, Cambridge.

[33] International Bank for Reconstruction and Development (IBRD) (1985) Kenya Second Livestock Development Project. Credit 477-KE Completion Report.

[34] KFS (2012) Leroghi/Kirisia Forest Management Plan (2012-2016). KFS, Nairobi.

[35] Mwaura, F. (2006) Assessment of Natural Resource Utilization in Samburu and Laikipia with Special Emphasis on Namunyak, Kalama and Naibunga Conservancies. Report for the AU-IBAR Dryland Livestock Wildlife Environment Interface Project (DLWEIP-KENYA), African Conservation Centre (ACC), Nairobi.

[36] FAO (2013) A Fire Baseline for Tanzania. Sustainable Forest Management in a Changing Climate. FAO-Finland Forestry Programme, Tanzania.

[37] Campbell, R.E., Baker, M.B. and Folliott, P.F. (1977) Wildfire Effects on a Ponderosa Pine Ecosystem: An Arizona Case Study”. USDA Forest Service Papers, RM-191. Rocky Mountain Forest and Range Experimental Station, Fort Collins, Colorado.

[38] O’Keefe, P., Raskin, P. and Bernow, S. (Eds) (1984) Energy and Development in Kenya: Opportunities and Constraints, Energy, Environment and Development in Africa. The Beijer Institute and Scandinavian Institute.

[39] Musoga, H. (1988) The Rural Energy Problem: A Case Study of Food Fuel in Shiswa Sub-Location, Kakamega District. MA Thesis, University of Nairobi, Nairobi.

[40] Mugo, F.W. (1989) Wood Fuel Demand and Supply in a Rural Set-Up: A Case Study of Naitiri Sub-Location, Bungoma District. MA Thesis, University of Nairobi, Nairobi.

[41] Ogolla, B.D. and Mugabe, J. (1996) Land Tenure Systems and Natural Resources Management. In: Juma, C. and Ojwang, J.B., Eds., Land We Trust: Environmental, Private Property and Constitutional Change, Initiatives Publishers, Nairobi.

[42] Mugabe, J., Njeri, M. and Mukii, D. (1998) Biodiversity Management in Kenya. In: Mugabe, J. and Norman, C., Eds., Managing Biodiversity: National Systems of Conservation and Innovation in Africa, African Centre for Technology Studies (ACTS) Press, Nairobi.

[43] Lambrechts, C., Woodley, B. and Gachanja, M. (2005) Aerial Survey of the Threats to Leroghi (Kirisia) Forest Reserve. Nairobi.

\section{Submit or recommend next manuscript to SCIRP and we will provide best service for you:}

Accepting pre-submission inquiries through Email, Facebook, LinkedIn, Twitter, etc.

A wide selection of journals (inclusive of 9 subjects, more than 200 journals)

Providing 24-hour high-quality service

User-friendly online submission system

Fair and swift peer-review system

Efficient typesetting and proofreading procedure

Display of the result of downloads and visits, as well as the number of cited articles

Maximum dissemination of your research work

Submit your manuscript at: http://papersubmission.scirp.org/ 